\title{
土木工事にみる生コンクリートの問題点 と監督者の心得
}

飯岡豊 ${ }^{*}$

\section{1.まえがき}

しばらく続いた減速経済時代を反映してか“量より 質”が重視される世の中となってきた。

近年土木の分野でも，増加する工事量に対応するため 省力化, 分業化を推し進めてきた結果, 現在では設計か ら施工までのほとんどの工種を専門業者が実施するとい ら型が定着しており，コンクリートの施工においてもこ の現象は顕著で，生コンとコンクリートポンプに集約さ れている感がある。

このような情勢のもとで, 生コンの果した功績は非常 に大きいものであったのはいうまでもないが，同時にそ の伸長もめざましく，ここ数年の年閒総生産量は 1.3 1.5 億 $\mathrm{m}^{3}$ にも達し, 生産されるセメント量の約 $60 \%$ が 生コンに使用されている現況である。また，コンクリー トポンプの普及と性能の向上もめざましく, 土木で一般 に使用される低スランプのコンクリートに十分対応でき る機種も数多く出現している。

しかしその反面, 工事の増大, 分業化がもたらした影 響は甚大で, 骨材の枯渴からその多様化, 低品質化をき たしてコンクリートの品質を低下させ，技術者不足から 品質，施工管理を不十分にし，更には技術レベルの低下 をきたしている。また，施工の面ではコンクリートポン プの普及により施工の急速化が可能となったが，使用法 に適正を欠くことが多く，全体の流れとして能率をあげ ることに終始し, 出来上った構造物の品質については二 の次にされてきた感は否めない。この結果は当然, 耐久 性の低下を招き, 長期的にみると図り知れない社会的損 失をきたしているのではなかろらか。

一方, コンクリート構造物に対する需要は増加する方 向にあり，例えば，橋りょうにおいてはメンテナンスフ リーに加え振動や騒音公害の点などからも, 鋼構造物よ

* 正会員 日本道路公団試験所コンクリート試験室長

Vol. 15, No. 6, June 1977
りコンクリート系構造物の優位性が認められてきている ので，ますますこの傾向は著しくなるといえよう。

このような情勢をふまえ“より良いコンクリート構造 物を造る”た的に監督者は，現状を正確に把握し，原点 にかえって考え直す必要があると思われる。

\section{2. 現状の問題点}

\section{1 発注者側の管理体制}

現状のように，技術者不足が慢性化し発注者側がもっ ぱら，工程管理は日報，月報など，品質管理は管理週報 などの施工業者から提出される書類によって事後承諾の ような形で行われると，監督者は本来の業務である“設 計図書に記載された所定の品質を満足させる構造物を造 るよう施工業者を指導, 監督する”ことができなくなっ てしまうことが多い。コンクリート技術には多分に現場 的，経験的な要素があるので，この結果は技術レベルの 低下につながることとなり，現状はまさに，このような 状態にたち至っているのではなかろらか。

一方，施工者側も同様であり，コンクリートを安易に 考え下請の專門業者まかせにすることも多いため，品 質，施工管理の実態は非常にあいまいなものになってお り，所定の品質が確保されているかどうか甚だ疑わしい ような場合も数多く出ている現状である。

このような事態に加え品質, 施工管理をきでしく実施 すれば，より良い構造物が造られるという企業体質の実 情は甚だ遺憾であるが，このような状況のもとで対処す るには，やはり現場に扔ける指導，監督をきびしくする 以外には無いのではなかろうか。従って, 発注者側とし ての管理体制を再検討し, 造られているものの実態を把 握することが，より良い構造物を造っていくうえで是非 必要であると思われる。 


\section{2 施工業者の管理体制}

建設業法の改正などにより従来, 発注者主導型であっ た権限も，大幅に施工業者に委譲されている。

周知のように，施工業者は増加の一途をたどった工事 量に対応寸るため，省力化，分業化などを実施してきた が,この過程において工事のみならず責任までも分散し てしまった感があるのは否めない。コンクリート工事で は型わく, 鉄筋, 生コン, ポンプ施工などの業種に分け られているが，現場の施工者が一昔前のように自身で骨 材の選定から養生に至る一連の体験をしなくなったた め，専門業者にまかせきりになり易く，施工業者の責任 において管理すべき一連の専門業者を統轄できなくなっ ていることが多い。この結果が構造物の品質低下をきた している主要因となっている。

特に，生コンに関しては製品購入といら考え方が強 く, 施工者側が当然, 自ら行わなければならない受取り 検查, 打設地点での品質管理などを含め生コン側に依存 していることも多く，正常な姿とはいえないらえ，ます ます施工者側のコンクリートに関する認識を低下させる ことにもなり，責任感が欠除する原因ともなっている。

このような状況を施工者は再検討し，構造物工事に関 する一切の責任を持っているといら自覚のうえに，管理 体制について早急に対処し，コンクリートに関する不信 感を排除することが急務であると考えられる。

\section{3 生コンエ場について}

増大したコンクリートの需要に応じるため, 全国的に 急ピッチで増設された生コン工場の数は現在, 全国で約 4100, そのうち通産省の認可をうけた JIS 表示許可工 場は約 2000 といわれ，その規模や品質管理などは千差 万別といった状況を呈している。

これらの諸工場におけるプラント設備の点からみると 計量制御, 印字記録装置, 出荷管理装置などをコンピュ

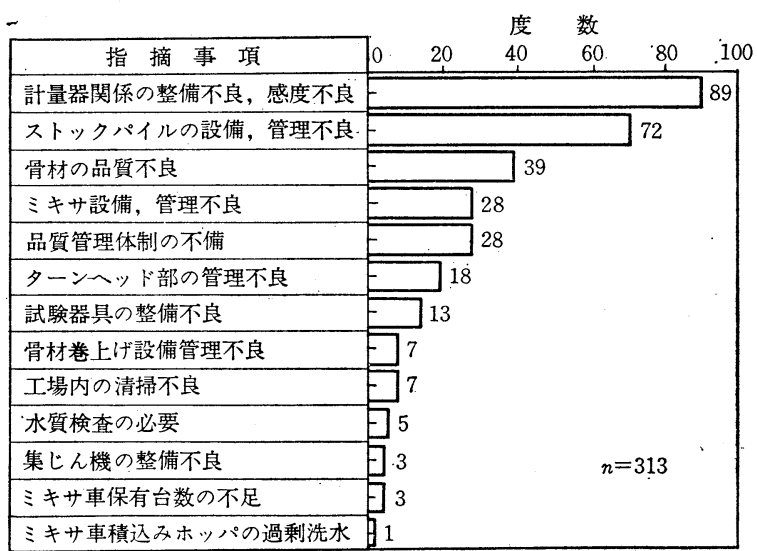

図一1 プラント検査における指摘事項の例
一タで一連の操作ができる完全自理化された工場からパ ンチカード方式，更には旧態依然としたプルワイヤ方式 の工場まで，その格差は非常に大きい。また，従事して いる技術者の数，レベルについても同様なことがいえる 状況であり，これらの格差が概して，製造している生コ ンの品質にも現れていると思われる。

日本道路公団において実施している生コン工場に関す る管理は，使用量も大きく長期間にわたることが多いの で，比較的きびしく行っている。具体的に注事業が全国 的に拡っているので, 工場規模の大きなところだけを選 定するわけにもいかないため, 工事着手前に対象となる 工場の立地条件，使用骨材等の材料，貯蔵施設，製造設 備, 品質管理体制及び運搬経路など全般にわたって検查 を実施し，不良箇所の指摘と改善の要求をしている。図 -1 はプラント検查実施時（対象 56 工場）の指摘事項 をとりまとめたものの一例であるが，現状の平均的な工 場の状態を代表しているように思われる。

また，生コン工場の中にはJIS 工場といえども，その JIS 表示が疑問に思われるような粗末な品質管理しか行 っていないところもあるので，事前に十分な調查を実施 することが必要である。特に, プラントの諸設備のうち 印字記録装置は配合指示值に対寸る計量誤差の確認，卜 ラブルの生じた場合の資料など，有効代利用できるので 是非，設置するよう指導したいものである。

\section{4 骨材の多様化と低品質化}

コンクリート需要の増大とともに骨材需要も増加した が，従来から骨材供給源であった河川からの採取規制が 強化されるようになったため, 供給源を他に求めざるを 得なくなり, 骨材の多様化現象を生じた。現状では, 粗 骨材の場合河川産のものが少なくなり山砕が主流となっ ており，この他陸砂利，山砂利などが使用されている。 細骨材の場合には一段ときびしく河川産のものはごくわ ずかで, その他海砂, 陸砂, 山砂, 砕砂などの使用 が一般化している。このような状況のもとで, コン クリート用骨材としては品質的に使用できないとさ れてきた粗悪な骨材をも使用せざるを得ない実情に あるため, 品質の変動範囲も非常に大きくなってい るとともに，総じて品質劣化の傾向が著しい。

従って，骨材は付近で得られるものを使用するこ とが原則ではあるが，使用に当ってはコンクリート 構造物の要求する品質を考慮し, 良質骨材が得られ ない場合には，その使用方法を検討することが必要 である。特に，寒冷地においては品質が悪いと，骨 材から凍結融解の被害をうけることがあるので，注 意が必要である。

图一2 は，日本道路公団において $47 \sim 50$ 年度に 


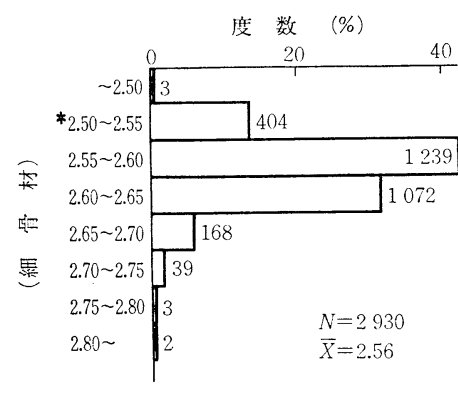

* 境界值のものを含む。 (以下同し)

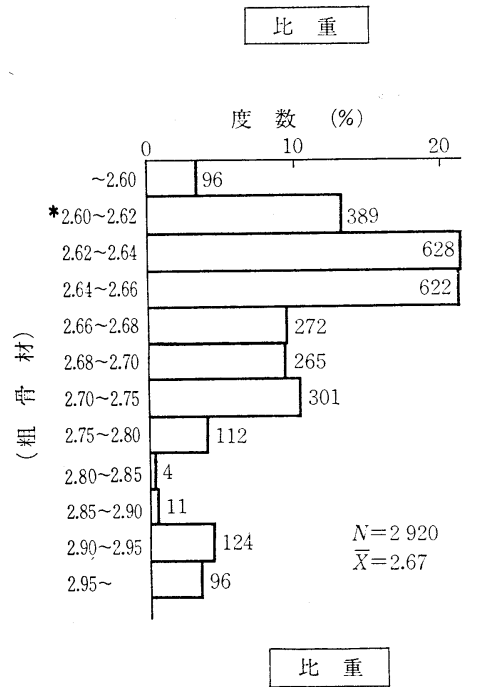

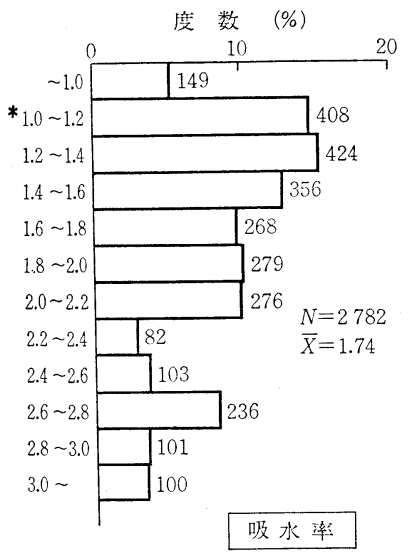
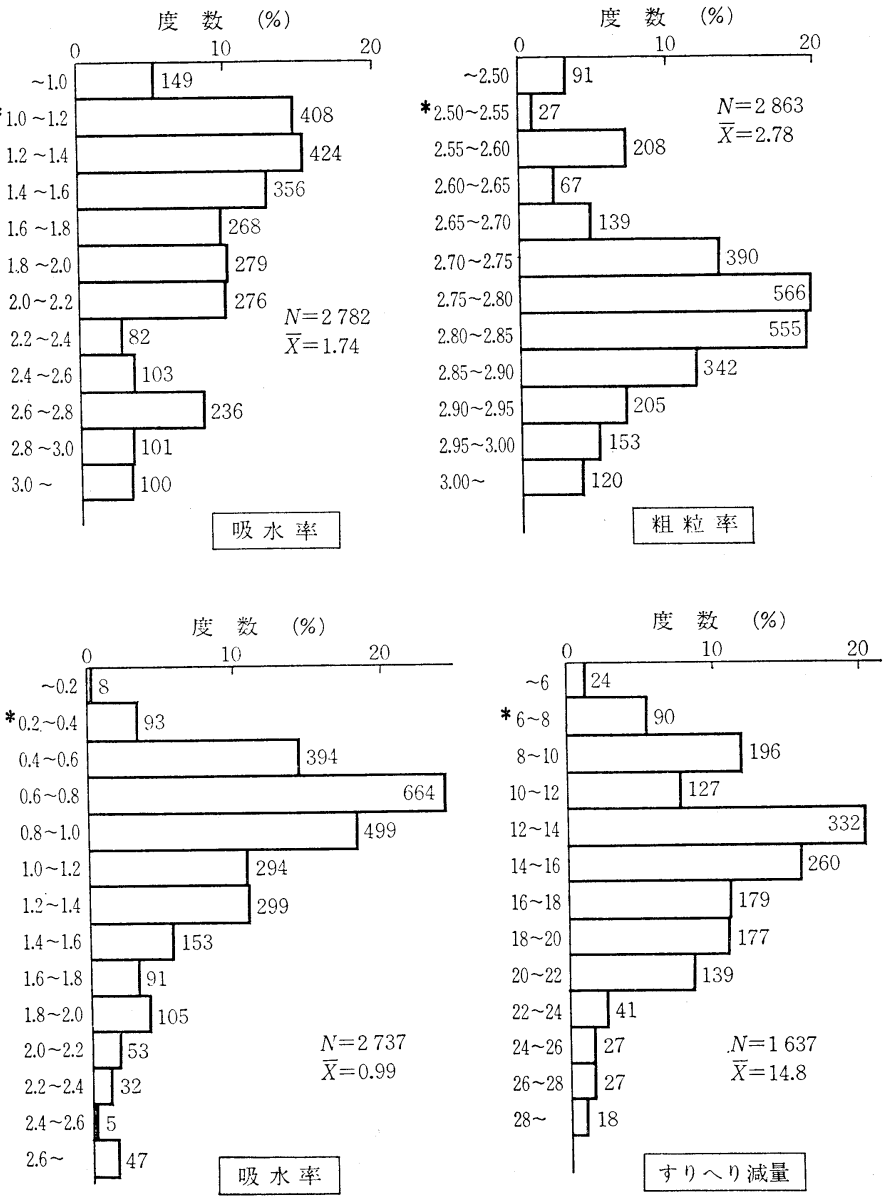

図一2 骨材の品質（昭和 47〜50 年度）

全国で使用された骨材の品質を集計したものである。

\section{5 骨材の多様化と低品質化に対応する使用法}

現在, コンクリートに課せられている大きな問題の一 つに, 骨材の多様化と低品質化に対応した適正な使用方 法を確立することがある。ここで問題となるのは骨材の 劣化や粒度, 粒形の悪化に伴う単位水量の増加がコンク リートの強度や耐久性の低下につながる点である。

この問題に関連して筆者のところでも “低品質骨材を 使用するための改良法”について試験を行っている。こ れは改良法として, (1)単位セメント量の増加, (2)細骨材 率の増減, (3)細骨材の粒度調整, (4)良質骨材の混合, (5) 高強度減水剂の使用について着目し, 圧縮強度, 而久性 指数, 乾燥収縮量などが単位量とどのような関係にある かを求めたものであり, 比較検討した結果, 最適細骨材 率を採用して行ったものが，コンクリートの強度及び耐 久性のうえで最も勝れているとの結論を得ている。

この結果をふまえて一例をあげると, 日本道路公団で は入札時, 施工業者一単価を算出するために暫定配合

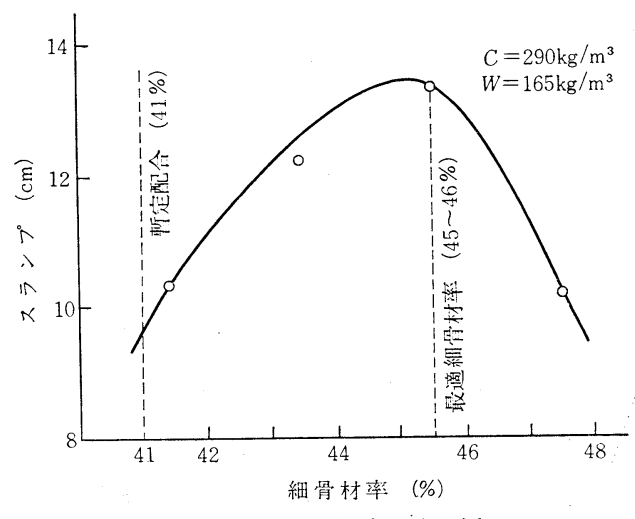

図一3最適細骨材率の決定例

（良質の骨材使用を前提）を提示しているが，使用する コンクリートの示方配合を決定するとき骨材の特性を考 えずに暫定配合で示された細骨材率を機械的に採用し， 単位水量はスランプだけで決められる場合が多い。図一 3 は比較的粒形の良くない砕石（実積率 $56.9 \%$ ) と海 砂を使用したコンクリートの配合試験例であるが, 単位 
セメント量, 単位水量を一定にし細骨材率を変化させた 場合, スランプは $3.5 \mathrm{~cm}$ 程度の増減を示している。こ の結果から試算してみると, 適当な細骨材率を選定すれ ば単位水量は約 $8 \mathrm{~kg}$ 減少し, 圧縮強度は約 $25 \mathrm{~kg}$ (約 10\%）増加することになる。従って, 現在一般的に行わ れているように, 低品質骨材はセメント量でカバーする と安易に考える前に最適細骨材率についての検討が必要 であろら。なぜなら，概略セメント量 $1 \mathrm{~kg} / \mathrm{m}^{3}$ は 28 日 圧縮強度 $1 \mathrm{~kg} / \mathrm{cm}^{2}$ に対応するので, この例では, 最適 細骨材率を用いて配合することにより，セメント量を約 $25 \mathrm{~kg} / \mathrm{m}^{3}$ 増加したものに相当する効果をもつからであ る。

なお, 低品質骨材の使用法については, 最適細骨材率 の採用が, 現状では効果的な対策の一つであるとして紹 介したが，これだけではカバーしきれない点も多々ある ので今後におけるこの面での研究を期待したい。

\section{6 コンクリートの品質亡管理}

我が国の高速道路は現在, 約 $2000 \mathrm{~km}$ が開通し, 更 に約 $3000 \mathrm{~km}$ が工事中である。この間に使用されたコ ンクリートの数量は膨大なものであるが，その品質を比 較するため建設順の名神 (小牧〜西宮, 施工期間 33.10. $\sim 40.6$ ), 中央道（調布～河口湖，同 40.4.４2.12.)，

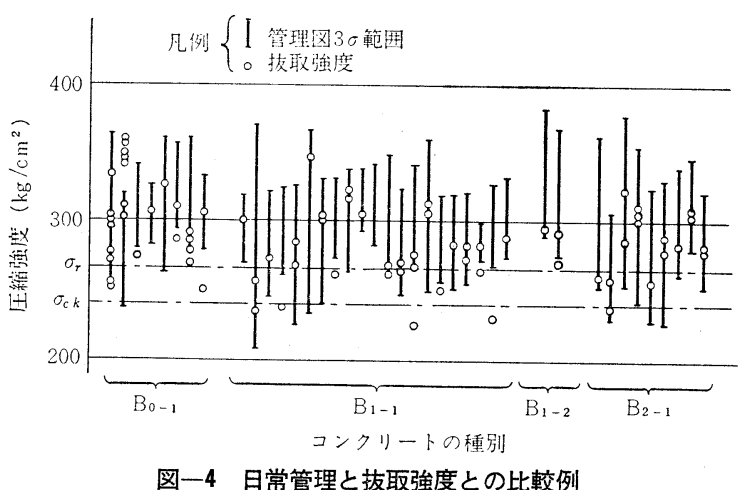

東名 (東京〜小牧, 同 40.4 44.5.) 及びその他幹線自 動車道（全国, 集計対象 47.4.〜50.12.) について集計 すると, 表一1 の通りである。

また，日常の品質管理データに関して疑問に思われる ことも多い。例えば，通常圧縮強度の管理データより算 出される変動係数は 2〜7\% の範囲にあることが多く, かなり安定した数值を示している。しかし，変動係数は 最大限の注意をしても $4.5 \%$ 以下にすることは難しいと いわれており，2〜3\% の変動係数はどのような管理を すれば可能になるのであろらか。一例として，日常管理 図から求めた $3 \sigma$ の範囲と, その対応する各工事におい て実施した抜取試験結果を比較してみると，図一4の通 りで，約 $20 \%$ が管理限界 $3 \sigma$ の範囲から逸脱している のが現状であるが……

\section{7 コンクリートポンプによる施エ}

コンクリートポンプによる施工は, 省力化, 急速化な どの面で著しいメリットがあり，現状では約 $75 \%$ の工 事でこの工法が採用されるに至っている。

その反面, コンクリート構造物の施工過程において最 も問題の多い部分となっている。その要因は, ポンプの 圧送効率がコンクリートのスランプ, セメント量, 細骨 材率の大きいほど高い本質的な性格と，これを使用する ポンプ業者と管理する施工業者のコンクリートに対 する認識の不足にあることが多い。このため, 固ま ったコンクリートの品質を考慮せずに，ややもする とポンプの圧送効率を上げることだけが重視される あまり，細骨材率を増加したり，極端な場合には水 を加えたりして必要以上に軟ねりコンクリートを使 用するという本末転倒なことになってしまう。コン クリートの単位水量を増せば, 当然の結果として強 度低下, 乾燥収縮の増加によるひびわれの発生, 耐 久性の低下などの問題が生じてくる。

また，圧送能力にみあった作業人員，バイブレー

表一1 高速道路に使用したコンクリート品質の比較 $\left(\mathrm{B}_{1-1}\right.$ コンクリート)*

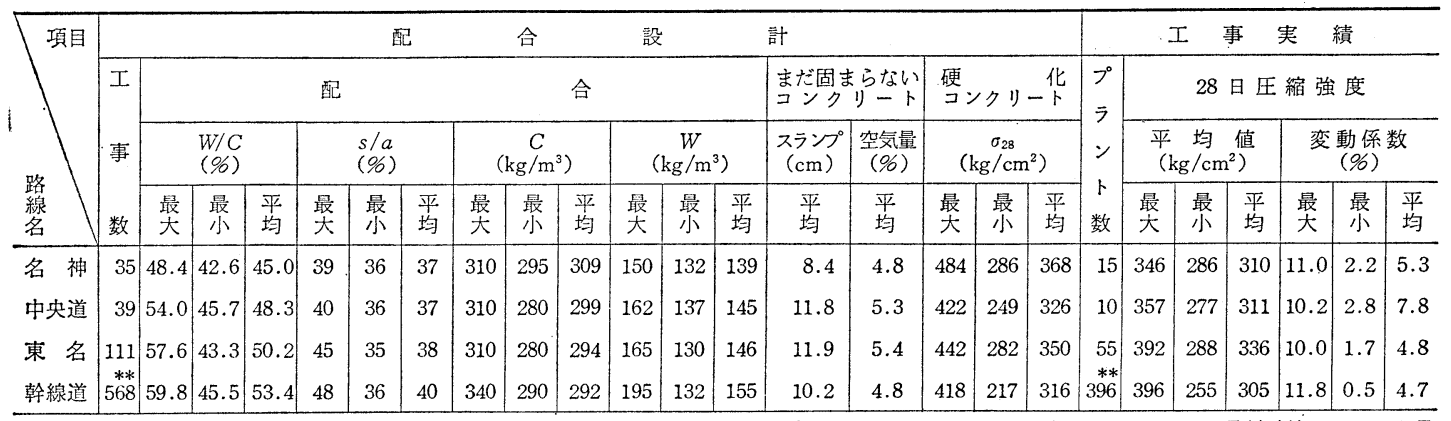

（注）*日本道路公団のコンクリート種別，設計基準強度 $240 \mathrm{~kg} / \mathrm{cm}^{2}$ ，スランプ $5 \sim 10 \mathrm{~cm}$ ，空気量 $3 \sim 6 \%$ ，サフィックスは骨材寸法・セメント量 及び種類を表す。

**工事数 $\times$ 打設期間（年度）数 


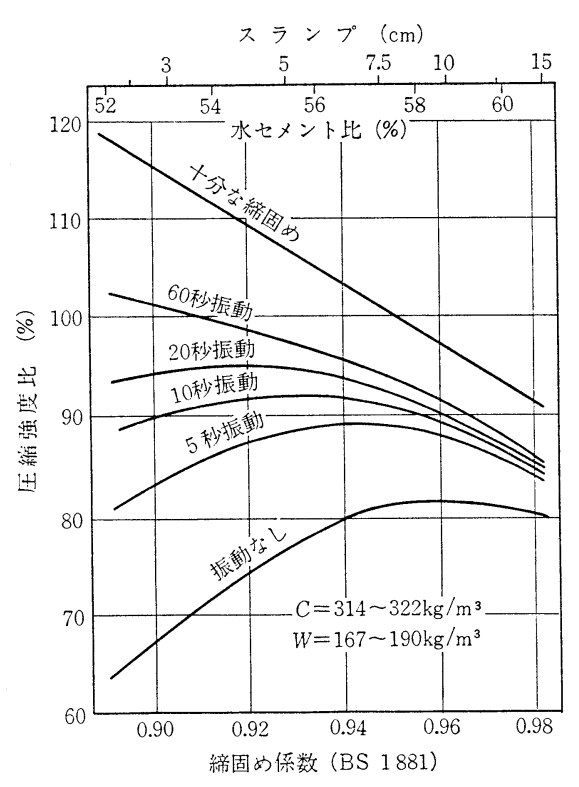

図一5 締固め強度と圧縮強度との関係

夕等の確保がなされていない場合も多く, 締固的不足の ためにコールドジョイント，豆板などの久陥現象を生じ たり，表面仕上げの粗雑さなどが目立っている。図一5 は B.S. Heaton による締固为程度と圧縮強度との関係 を示したものであるが，これからも締固め程度が強度に 与える影響は非常に大きなるのであることが分かる。

なお，現在ではコンクリートポンプの性能も全般的に 向上し，土木で一般使用する $8 \sim 12 \mathrm{~cm}$ 程度の低スラ ンプにも十分対応できるポンプも多数出回っているの でコンクリートの品質に合った 機種を採用することが必要であ る。な㧍，現場において所定のコ ンクリートを十分安全に圧送でき る機種が，得られないと判断した 場合には，監督者はコンクリート 打設を他の方法に変えるよう指導 すべきである。ちなみに、コンク リート建造物の安全を確保するた め，大阪府で作られた“コンクリ 一ト工法に関する指導要綱”によ ると, スランプ18 cm 以下のコン クリート打設には 4 インチ管の機 種の使用は禁止されている。

\section{8 設計との関連}

設計と施工との間において，相 互の認識不足からしばしば問題が 生じている。この矛盾を示す一例 として，現場で製作されるP C ポ

\section{表一2 コンクリート構造物の品質低下の原因と対策}

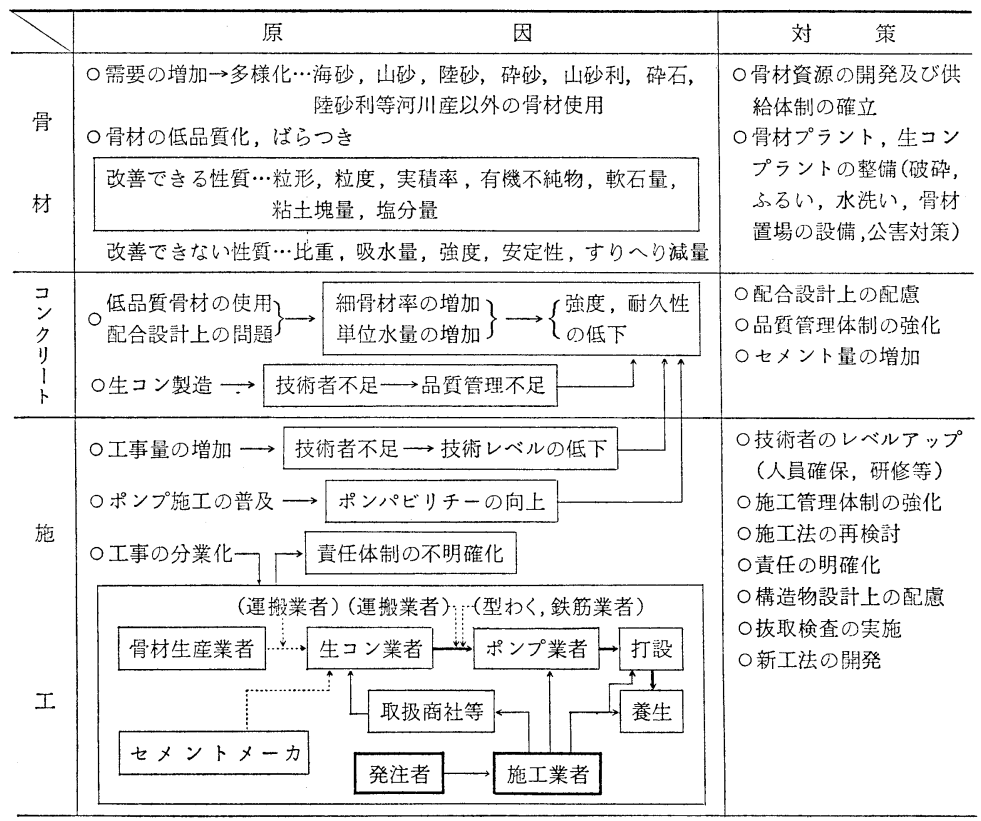

ストテンションげたのたわみの問題がある。すなわち, 設計側はその工事で使用されるコンクリートの特性を考 えずに, 設計示方書に示されている標準的なヤング率の 值を機械的に採用し設計計算を行う。一方, 施工者側注 仕様書で示されたスランプの許容される最大值を目標と したコンクリートを要求するため, 必然的にプレストレ スによるたわみ量が大きく出てキャンバーがつき過ぎて しまってあわてることも多く, 調べてみるとけたに使用 したコンクリートのヤング率が，設計值の約 75\% しか なかったなどということもある。この例なども設計と施 工が遊離してしまっているために生ずる一考を要する事 例であろう。

また，前に述べてきたように，一般に品質，施工管理 に弱点があると考えられる現状では，設計時点において プレキャストなどの工法を検討し，現場の合理化，集中 管理のうえで有効な施工の採用について，もっと積極的 に取り組む必要があるうと思われる。

\section{9 ま め}

以上の諸事項をまとめると，表一2 の通りである。

\section{3.あとがき}

コンクリート構造物は, 従来から永久構造物であると いわれている。この永久，いい換光ると耐用年数につい ては，いろいろな説があり定かではないが，50 年以上 であるという点では一致しているようである。 
土木におけるコンクリート構造物の種類は広範多岐に 亘っているので一概にはいえないが，特に耐久性につい て問題となっている例をあげると, 鋼道路橋の R C 床 版の場合がある。この要因である道路の交通実態をみる と, 一部には設計荷重の 2〜3 倍もあるような過載荷重 車が大手をふって横行している現況で, 供用後 10 年も 経たないのに劣化が激しく, 補強ないし打ち換えなどの 工事がなされる例も非常に多い。このような状況のもと で，品質あるいは施工が不良であった場合には，この影 響が相乗的に大きくなることは明白であり，例えば，高 速道路の場合のように, 同種のものが同じ時期に多数造
られ，同一交通が通っているのにも拘らず，その劣化の 度合には非常に大きな差があり，くしくも品質の良否が 歴然と対比されて現れることもある。

このような品質に格差がある傾向は他の場合について も当てはまることと思われるが，これが即，監督者及び 施工業者の技術レベル等の差がもたらした結果であると 判断されても，やむを得ないことではあるまいか。

\section{参 考 文 献}

1）中村修吾 : コンクリートの品質低下とその対策について 日本道路公団技術情報 26 号, 1975 年 1 月

2）桜井宏 : 生コンプラントと強度管理の現況と問題点につ いて, 日本道路公団技術情報 30 号, 1976 年 1 月

圆書案内四

\section{コンクリート技術の基礎 76}

\section{A 5 判上製 337 頁 定価 2,800 円 送料 200 円 会員特価 2,300 月 送料 200 円}

本書は, 土木学会コンクリート標準示方書, 日本建築学会 JASS 5 の改訂にともなう 「コンクリート技術の基礎'72」の改訂版であります。コンクリートの実務に携って おられる比較的初心の技術者を対象にコンクリート技術全般にわたって平易に解説し てあり,コンクリート技士試験受験の参考書としても好個のものであります。

\section{内 容}

I. 材料 1.1 セメント 1.2 骨材 1.3 軽量骨材 1.4 混和材料 1.5 鉄筋 1.6 水

II. 配合 2.1 配合の基礎知識 2.2 品質の変動 2.3 配合の手順（土木） 2.4 調合の 手順 (建築)

III. 性質 3.1 フレッシュコンクリートの性質 3.2 硬化コンクリートの性質（その1）

3.3 硬化コンクリートの性質（その 2 ）

IV. 製造 4.1 製造方法 4.2 品質管理

V. 施工 5.1 計画と準備 5.2 生コンの受入れと打込み締固め 5.3 養生

VI. コンクリート製品

\section{発行 所圆 社団法人 日本コンクリート工学協会}

105 東京都港区芝公園 1-5-10 芝パークホテル 310 電話 03-433-4131 内線 310,308 郵便振替口座東京 2-99133 